\title{
PENGARUH PENGINTEGRASIAN PENDIDIKAN KARAKTER BERORIENTASI KEARIFAN LOKAL KE DALAM MATERI AJAR MATA KULIAH ILMU LINGKUNGAN UNTUK MENINGKATKAN SOFT SKILL MAHASISWA JURUSAN PENDIDIKAN BIOLOGI FMIPA UNDIKSHA
}

\author{
Nyoman Wijana \\ Jurusan Pendidikan Biologi FMIPA \\ Universitas Pendidikan Ganesha \\ Singaraja, Indonesia \\ E-mail: wijana_1960@yahoo.com
}

\begin{abstract}
Abstrak
Tujuan penelitian ini adalah untuk mengetahui pengaruh pengintegrasian pendidikan karakter berorientasi kearifan lokal ke dalam materi ajar mata kuliah IImu Lingkungan untuk meningkatkan soft skill mahasiswa Jurusan Pendidikan Biologi Fakultas Matematika dan IImu Pengetahuan Alam Undiksha.Jenis penelitian ini termasuk jenis penelitian quasi eksperimen. Rancangan penelitian ini menggunakan rancangan randomized pre-test and post-test control group design. Populasi target pada penelitian ini adalah seluruh mahasiswa yang ada di Jurusan Pendidikan Biologi Fakultas Matematika dan Ilmu Pengetahuan Alam Undiksha, sedangkan populasi terjangkaunya adalah mahasiswa semester I yang mengikuti mata kuliah Ilmu Lingkungan. Sampel penelitian ini adalah mahasiswa semester I yang terdiri atas tiga kelas.Dengan menggunakan teknik random sampling, diambil dua kelas yang digunakan sebagai sampel penelitian.Dari dua kelas tersebut selanjutnya dirandom lagi untuk menentukan kelas eksperimen dan kelas control. Data dianalisis secara statistik. Hasil penelitian menunjukkan bahwa pengaruh pengintegrasian pendidikan karakter berorientasi kearifan lokal ke dalam materi ajar mata kuliah IImu Lingkungan dapat meningkatkan soft skill mahasiswa di mana hasil penilaian setelah proses pembelajaran pada kelompok kontrol sebesar (13.03) dan pada kelompok eksperimen sebesar $(23,62)$. Setelah diuji menggunakan independent $t$-test, nilai soft skill setelah pembelajaran menunjukkan perbedaan yang bermakna dengan nilai $p<0,05$. Simpulan yang dapat disampaikan adalah bahwa pengintegrasian pendidikan karakter berorientasi kearifan lokal ke dalam materi ajar mata kuliah IImu Lingkungan dapat berpengaruh peningkatan soft skill mahasiswa Jurusan Pendidikan Biologi Fakultas Matematika dan IImu Pengetahuan Alam Undiksha.
\end{abstract}

Kata Kunci: pendidikan karakter, kearifan lokal, soft skill

\begin{abstract}
The purpose of this research was to know the effect of integrating local wisdom oriented character education into teaching materials course in Environmental Sciences to improve the soft skills of students of Education Department of Biology, Faculty of Mathematics and Natural Sciences Undiksha. The kind of this research, including the type of quasi- experimental research.The design of this research using a randomized design of the pre-test and post-test control group design. Target population in this study were all students in the Education Department of Biology, Faculty of Mathematics and Natural Sciences Undiksha, while the population of inaccessibility is the first semester students who follow courses in Environmental Sciences. The samples of this research were students of first semester consisting of three classes. By using the technique of random sampling, taken two classes are used as samples. Of the two classes are then randomized again to determine the experimental class and control class. Data were analyzed statistically. These results of this research indicate that the effect of integrating local wisdom oriented character education into teaching materials course in Environmental Sciences can improve the soft skills of students in which the results of the assessment after the learning process for the control group (13.03) and the experimental group was (23.62). Having tested using independent t-test, after learning attitude score showed a significant difference with $p<0.05$. Conclusions of this research that can be delivered is that the
\end{abstract}


integration of character education-oriented local wisdom into teaching materials course in Environmental Sciences can affect soft skills increase student Education Department of Biology, Faculty of Mathematics and Natural Sciences Undiksha.

Keywords: Character Education, Local Wisdom, Soft Skill.

\section{PENDAHULUAN}

Telah banyak kita ketahui dari berbagai media cetak maupun elektronik, bahwa telah terjadi tawuran di jalanan antara kelompok orang dari sekolah tertentu dan bahkan dari mahasiswa perguruan tinggi tertentu. Kondisi ini sangat memprihatinkan, di mana sebenarnya orang yang memiliki intelektual tinggi, kecerdasan, keilmuan dan pandangan yang luas, melakukan tawuran, yang hanya disebabkan oleh faktor dan masalah yang kecil.

Di samping itu, etika dan sopan santun mahasiswa di kampus maupun di luar kampus semakin menurun. Banyak dosen telah menyatakan keluhannya bahwa etika berkomunikasi mahasiswa dengan dosen tidak mengenal anggah ungguh, tidak mengenal situasi, tidak memperhatikan kondisi psikologis lawan bicara, dan kurang memperhatikan posisi dirinya dan orang lain.

Berdasarkan uraian singkat mengenai kondisi karakter siswa dan mahasiswa saat ini, maka dipandang perlu adanya pendidikan karakter. Pendidikan karakter yang dimaksud adalah pendidikan yang memiliki esensi dan makna yang sama dengan pendidikan moral dan pendidikan akhlak. Tujuannya adalah membentuk pribadi anak, supaya menjadi manusia yang baik, warga masyarakat, dan warga negara yang baik. Beberapa nilai karakter dasar meliputi cinta kepada Tuhan Yang Maha Esa, peduli terhadap alam dan isinya, tanggung jawab, jujur, hormat dan santun, kasih sayang, peduli, kerjasama, percaya diri, kreatif, kerja keras, pantang menyerah, keadilan kepemimpinan, baik, rendah hati, toleransi, cinta damai dan cinta persatuan. Lebih lanjut Depdiknas (2010) menyebutkan telah teridentifikasi 18 nilai yang bersumber dari agama,
Pancasila, budaya dan tujuan pendidikan nasional.

Disiplin, percaya diri dan mandiri merupakan nilai pendidikan karakter yang perlu ditanamkan kepada siswa agar siswa memiliki karakter tersebut. Dengan pendidikan karakter tersebut siswa akan lebih berprestasi. Hal ini sesuai dengan pendapat Raka, dkk (2011: 204) "pendidikan karakter yang dilakukan dengan benar akan meningkatkan prestasi akademik siswa". Siswa yang berprestasi dan memiliki karakter yang baik merupakan tujuan pendidikan nasional. Hal tersebut tertuang dalam Undang-Undang Sistem Pendidikan Nasional No. 20 tahun 2003 pasal 3 yang berbunyi: Perlunya pendidikan karakter ditanamkan kepada siswa juga disampaikan oleh Berkowitz dalam Asmani (2011: 44) sekolahsekolah yang menerapkan pendidikan karakter, terjadi peningkatan motivasi siswa dalam meraih prestasi akademik. Hal ini berarti, dengan termotivasinya siswa dalam meraih prestasi akan mengakibatkan siswa akan belajar dengan rajin yang nantinya prestasi belajar siswa akan meningkat atau bertambah bagus

Menurut Khan (2010) pendidikan karakter mengajarkan kebiasaan cara berpikir dan perilaku yang membantu individu untuk hidup dan bekerjasama sebagai keluarga, masyarakat dan bernegara dan membantu mereka untuk membuat keputusan yang dapat dipertanggungjawabkan. Dengan kata lain pendidikan karakter mengajarkan anak didik berpikir cerdas, mengaktivasi otak tengah secara alami. Menurut Nugroho (2011) pendidikan karakter adalah suatu penanaman nilai-nilai karakter kepada sekolah yang meliputi komponen 19 pengetahuan, kasadaran atau kemauan dan tindakan untuk melaksanakan nilai-nilai tersebut, baik terhadap Tuhan Yang Maha Esa, diri 
sendiri, sesama, lingkungan, maupun kebangsaan sehingga menjadi manusia kami.

Menurut Buchori (2007) pendidikan karakter seharusnya membawa peserta didik ke pengenalan nilai secara kognitif, penghayatan nilai secara afektif, dan akhirnya ke pengamalan nilai secara nyata. Menurut Lickona (2007), tanpa ketiga aspek ini, maka pendidikan karakter tidak akan efektif, dan pelaksanaannya pun harus dilakukan secara sistematis dan berkelanjutan.

Pengembangan pendidikan karakter tidak lepas dari budaya yang ada di suatu tempat di mana pendidikan karakter itu diselenggarakan. Salah satu dari budaya yang ada dan turun temurun di masyarakat adalah kearifan lokal. Kearifan lokal merupakan kecerdasan manusia yang dimiliki oleh kelompok etnis tertentu yang diperoleh melalui pengalaman masyarakat. Artinya, kearifan lokal adalah hasil dari masyarakat tertentu melalui pengalaman mereka dan belum tentu dialami oleh masyarakat yang lain. Nilainilai tersebut akan melekat sangat kuat pada masyarakat tertentu dan nilai itu sudah melalui perjalanan waktu yang panjang, sepanjang keberadaan masyarakat tersebut (Erwan, 2012; Mundilarto. 2013; Sartini, 2004).

Hasil kajian terhadap penelitianpenelitian yang dilakukan oleh dosendosen Undiksha menunjukkan bahwa dari jumlah penelitian secara keseluruhan untuk tahun 2009 ada sebanyak 168 buah penelitian, yang mana dari jumlah tersebut berorientasi ke arah penelitian kecakapan hidup (life skills) hanya mencapai jumlah 43 buah $(25,52 \%)$. Dari 43 buah penelitian yang berorientasi kecakapan hidup tersebut, penelitian yang paling rendah persentase penelitiannya yang berorientasi ke life skills adalah jenis penelitian Pekerti, DIPA (PPKP), DIPA PIPS, dan Tracer study masing-masing $0 \%$, menyusul jenis penelitian
Fundamnetal dan Hibah Kompetensi sebesar 2,32\%. Yang paling besar persentasenya adalah Hibah Bersaing kemudian diikuti oleh DIPA Lanjut $(27,91 \%)$ dan Stranas (25,58\%) (Wijana dan Dharmadi, 2012).

Dari data di atas tampak bahwa penelitian yang mengarahkan ke soft skill mahasiswa belum nampak secara jelas. Oleh karena itu dipandang penting untuk melakukan penelitian dalam rangka peningkatan soft skill mahasiswa melalui pelaksanaan pendidikan karakter berorientasi kearifan lokal yang diintegrasikan ke dalam materi ajar perkuliahan. Tujuan dari penelitian ini adalah untuk mengetahui pengaruh pengintegrasian pendidikan karakter berorientasi kearifan lokal ke dalam materi ajar mata kuliah IImu Lingkungan untuk meningkatkan soft skill mahasiswa Jurusan Pendidikan Biologi FMIPA Undiksha.

\section{METODE}

Jenis penelitian yang dilakukan ini termasuk jenis penelitian quasi eksperimen, yaitu pengambilan sampel dari populasi yang ada diadakan secara random pada tingkat kelas dan bukan pada tingkat siswa secara individual. Rancangan penelitian ini menggunakan rancangan randomized pre-test and post-test control group design (Pocock, 1986). Rancangan penelitian yang dimaksud dapat pada Gambar 1.

Kelompok kontrol adalah kelas yang tidak diberikan perlakuan berupa pendekatan konvensional di mana kelas yang diberikan perlakuan berupa pembelajaran tanpa pengintegrasian pendidikan karakter berorientasi kearifan lokal ke dalam materi ajar pada mata kuliah Ilmu Lingkungan.Kelompok eksperimen adalah kelas yang diberikan perlakuan berupa pembelajaran pengintegrasian pendidikan karakter berorientasi kearifan lokal ke dalam materi ajar pada mata kuliah IImu Lingkungan. 


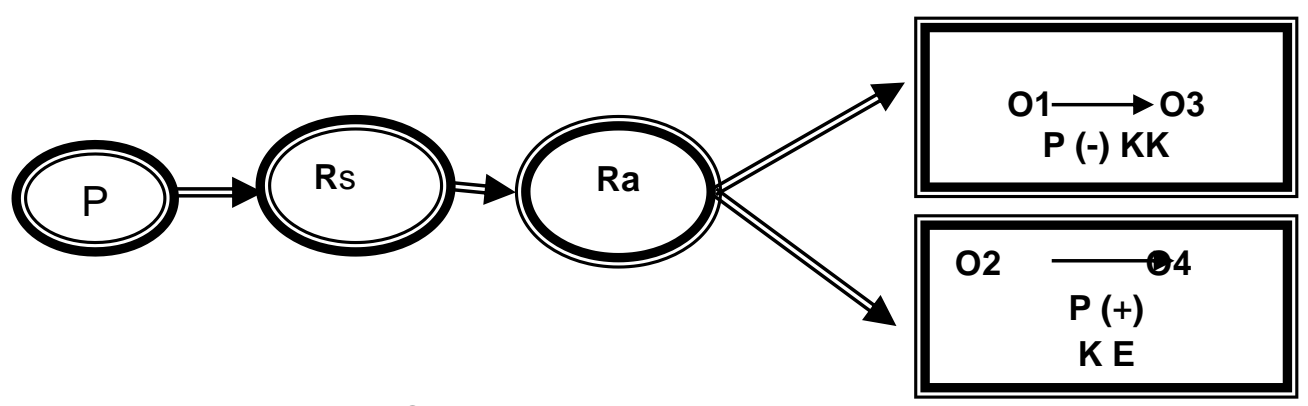

Keterangan:

Gambar 1 Rancangan Penelitian

$$
\begin{aligned}
\mathrm{P}= & \text { Populasi } \\
\mathrm{Rs}= & \text { Random sampling } \\
\mathrm{Ra}= & \text { Random alokasi (penentuan } \\
& \text { kelompok kontrol dan } \\
& \text { kelompok eksperimen) } \\
\mathrm{KK}= & \text { Kelompok Kontrol } \\
\mathrm{KE}= & \text { Kelompok Eksperimen }
\end{aligned}
$$

Populasi target pada penelitian ini adalah seluruh mahasiswa yang ada di Jurusan Pendidikan Biologi FMIPA Undiksha, sedangkan populasi terjangkaunya adalah mahasiswa yang mengikuti mata kuliah IImu Lingkungan yakni mahasiswa semester I tahun ajaran 2014/2015.

Sampel penelitian ini adalah mahasiswa yang mengambil mata kuliah Ilmu Lingkungan, yakni mahasiswa semester I. Mahasiswa semester I terdiri atas tiga kelas. Dengan menggunakan teknik random sampling sederhana (menggunakan undian), diambil dua kelas yang digunakan sebagai sampel penelitian. Dari dua kelas tersebut selanjutnya dirandom lagi untuk ditentukan yang dijadikan kelas eksperimen dan kelas kontrol.

Variabel dalam penelitian ini adalah sebagai berikut. 1) Variabel bebas, yaitu variabel yang dimanipulasi secara sistematis. Variabel bebas dalam penelitian ini adalah pembelajaran dengan pengintegrasian pendidikan karakter ke dalam materi ajar pada mata kuliah IImu Lingkungan dan pembelajaran tanpa pengintegrasian (secara konvensional). 2) Variabel terikat, yaitu variabel yang diukur sebagi akibat adanya manipulasi pada variabel bebas. Variabel terikat dalam penelitian ini adalah soft skill mahasiswa.

$$
\begin{gathered}
\text { O1\&O2 } \begin{array}{c}
=\text { Data sebelum } \\
\text { eksperimen }
\end{array} \\
\begin{aligned}
\text { O } 3 \text { \& Ota setelah } \\
\text { eksperimen }
\end{aligned} \\
\begin{array}{c}
(\mathrm{p}-)=\text { tanpa perlakuan } \\
(\mathrm{p}+)=\text { diberikanperlakuan }
\end{array}
\end{gathered}
$$

Adapun metode pengumpulan data dalam penelitian ini didasarkan atas rumusan masalahnya yaitu: a. Terkait dengan model pembelajaran yang akan digunakan dalam pembelajaran ini dikumpulkan dengan metode wawancara, penilaian ahli dan penilaian tim pengajar; b. Data yang terkait dengan soft skill yang dimiliki oleh mahasiswa dikumpulkan dengan metode wawancara, kuesioner, check list, dan observasi; dan c. Data yang terkait dengan kendala-kendala yang dihadapi dalam pembelajaran ini dikumpulkan dengan metode wawancara. Persiapan yang dilakukan sebelum proses penelitian berlangsung.

a) Melakukan komunikasi lebih jauhdengan mahasiswa sampel penelitian. Hal ini bertujuan agar penelitian berjalan lebih kondusif dan dipahami oleh semua pihak.

b) Mempersiapkan semua keperluan alat/instrumen pengumpul data.

c) Menyiapkan dan memberi latihan kepada petugas pengumpul data (mahasiswa dari semester lain) tentang hal-hal yang berhubungan dengan proses penelitian, dimulai dari sebelum perlakuan sampai diberikannya perlakuan. Petugas pengumpul data ada sebanyak 6 orang.

Persiapan dosen selaku peneliti mengkondisikan mahasiswa untuk siap mengikuti perkuliahan yakni 
pengintegrasian pendidikan karakter berorientasi kearifan lokal ke dalam materi ajar dalam mata kuliah IImu Lingkungan (untuk kelas eksperimen) dan tanpa pengintegrasian pendidikan karakter berorientasi kearifan lokal ke dalam materi ajar dalam mata kuliah IImu Lingkungan (untuk kelas kontrol). Mahasiswa siap bekerja lapangan serta menjaga etika di dalam melakukan wawancara. Menyusun Nilai-nilai pendidkan karakter, kearifan lokal, dan soft skill yang rencananya dikembangkan. Persiapan mahasiswa:

1) Mahasiswa diharapkan sudah mengetahui jadwal mata kuliah sehingga tidak ada mahasiswa yang terlambat memasuki ruang kuliah.

2) Mahasiswa diharapkan mengikuti perkuliahan sesuai dengan model pembelajaran yang telah dirancang.

3) Mahasiswa yang dijadikan subyek penelitian, baik sebagai kelompok kontrol maupun sebagai kelompok eksperimen selama penelitian ini berlangsung diminta untuk mengisi kuesioner, check list, menjawab pertanyaan yang diajukan pada saat wawancara secara jujur.

4) Melaksanakan tugas-tugas yang diberikan oleh dosen; dan
5) Tidak ada mahasiswa yang absen selama proses penelitian ini berlangsung.

Instrumen penelitian yang terkait dengan peningkatan soft skill dapat dilakukan dengan menggunakan check list pedoman wawancara, dan lembar observasi. Data yang telah terkumpul selanjutnya dianalisis secara deskriptif. Untuk melihat perbedaan soft skill di antara kelompok eksperimen dan kelompok kontrol dilakukan analisis deskriptif semi kuantitatif mengacu Kemendikbud (2013).

\section{HASIL DAN PEMBAHASAN}

Data kondisi mahasiswa dalam penelitian ini meliputi sikap siswa selama pelajaran IImu Lingkungan berlangsung. Sikap yang diobservasi sebanyak 8 sikap, yaitu sikap spiritual, jujur, disiplin, santun, gotong royong, tanggung jawab, percaya diri, dan sikap toleransi.Sikap ini diamati pada kelompok kontrol dan kelompok eksperimen.

Dari data kondisi mahasiswa atau data tentang subyek penelitian sebelum perlakuan yang disampaikan tersebut, selanjutnya dianalisis secara statistik untuk mencari rerata, simpangan baku, dan nilai $p$ baik pada kelompok kontrol maupun kelompok eksperimen. Hasil analisis tersebut dapat direkapitulasi seperti disajikan pada Tabel 1.

Tabel.1 Hasil Rerata, Simpangan Baku, dan Uji Normalitas Sikap Mahasiswa Sebelum dan Sesudah Proses Pembelajaran, Selisih Sikap Mahasiswa Sebelum Proses Pembelajaran dengan Selisih Sikap Mahasiswa Sesudah Proses Pembelajaran

\begin{tabular}{|c|c|c|c|c|c|c|c|c|c|}
\hline \multirow[t]{2}{*}{ Variabel } & \multicolumn{2}{|c|}{$\begin{array}{l}\text { Kelas } \\
\text { Kontrol } \\
\mathrm{N}=30\end{array}$} & \multirow[t]{2}{*}{ Ket } & \multicolumn{2}{|c|}{$\begin{array}{c}\text { Kelas } \\
\text { Eksperimen } \\
\mathrm{N}=30\end{array}$} & \multirow{2}{*}{$\begin{array}{c}\text { Ket } \\
\text {. }\end{array}$} & \multirow{2}{*}{$\begin{array}{c}\text { Beda } \\
\text { Rerat } \\
\quad \mathrm{a}\end{array}$} & \multirow{2}{*}{ Nilai $p$} & \multirow[t]{2}{*}{ Ket } \\
\hline & $\begin{array}{l}\text { Skor } \\
\text { rerata }\end{array}$ & SB & & $\begin{array}{l}\text { Skor } \\
\text { rerata }\end{array}$ & SB & & & & \\
\hline $\begin{array}{l}\text { Sikap mahasiswa } \\
\text { sebelum proses } \\
\text { pembelajaran }\end{array}$ & 11.84 & $\begin{array}{c}0.5 \\
0\end{array}$ & $\mathrm{~N}$ & 12.44 & 0.63 & $\mathrm{~N}$ & -0.60 & $\begin{array}{c}p= \\
0.001\end{array}$ & B \\
\hline $\begin{array}{l}\text { Sikap mahasiswa } \\
\text { sesudah proses } \\
\text { pembelajaran }\end{array}$ & 13.03 & $\begin{array}{c}0.8 \\
3\end{array}$ & $\mathrm{~N}$ & 23.62 & 1.09 & $\mathrm{~N}$ & -10.58 & $\begin{array}{c}p= \\
0.001\end{array}$ & B \\
\hline $\begin{array}{l}\text { Selisih Sikap mahasiswa } \\
\text { sebelum proses } \\
\text { pembelajaran dengan } \\
\text { selisih Sikap mahasiswa } \\
\text { sesudah proses } \\
\text { pembelajaran }\end{array}$ & 1.19 & $\begin{array}{c}0.9 \\
2\end{array}$ & $\mathrm{~N}$ & 11.18 & 1.57 & $\mathrm{~N}$ & -9.97 & $\begin{array}{c}p= \\
0.001\end{array}$ & B \\
\hline
\end{tabular}


Keterangan

$\mathrm{KK}=$ Kelompok Kontrol

$\mathrm{KE}=$ Kelompok Eksperimen $\mathrm{B}=$ Bermakna

$\mathrm{SB}=$ Simpangan Baku

$\mathrm{N}=$ Data berdistribusi Normal

Dari Tabel 1 tampak bahwa terdapat perbedaan sikap mahasiswa sebelum pembelajaran pada kelas kontrol dan kelas eksperimen menunjukkan interval rerata yang berarti. Pada kelas kontrol rerata sikap sebelum pembelajaran sebesar 11, 84. Sedangkan rerata sikap pada kelas eksperimen sebesar 12,44. Hasil uji independent $t$ test menunjukkan nilai yang bermakna $(p<0,05)$. Sedangkan, pada sikap setelah pembelajaran pada kelas kontrol dan kelas eksperimen menunjukkan interval rerata yang berarti. Pada kelas kontrol rerata sikap sebelum pembelajaran sebesar 13,03. Sedangkan rerata sikap pada kelas eksperimen sebesar 23,62. Hasil uji independent $t$ test menunjukkan nilai yang bermakna $(p<0,05)$. Pada selisih sikap sebelum dan setelah pembelajaran pada kelas kontrol dan kelas eksperimen menunjukkan interval rerata yang berarti. Pada kelas kontrol rerata sikap sebelum pembelajaran sebesar 1,20. Sedangkan rerata sikap pada kelas eksperimen sebesar 1,57. Hasil uji independent $t$ test menunjukkan nilai yang bermakna ( $p<0,05)$. Selanjutnya secara lebih rinci dianalisis pula keseluruhan sikap mahasiswa sebelum pelaksanaan pembelajaran baik pada kelompok kelas kontrol maupun pada kelompok kelas eksperimen dengan hasil disajikan pada Tabel 2.

Tabel 2.Hasil uji statistik Independent $t$-test dari data Pre-test Kelas Kontrol dengan Pre-test Kelas Eksperimen Secara Umum Dari Keseluruhan Sikap

\begin{tabular}{|c|c|c|c|c|c|c|c|c|}
\hline & \multicolumn{2}{|c|}{$\begin{array}{c}\text { Kelompok } \\
\text { Kontrol }\end{array}$} & \multirow[t]{2}{*}{ Ket. } & \multicolumn{2}{|c|}{$\begin{array}{c}\text { Kelompok } \\
\text { Eksperimen }\end{array}$} & \multirow[t]{2}{*}{ Ket. } & \multirow{2}{*}{$\begin{array}{c}\text { Nilai } \\
\mathrm{p}\end{array}$} & \multirow[t]{2}{*}{ Keterangar } \\
\hline Variabel & Rerata & SB & & Rerata & SB & & & \\
\hline Spiritual & 1.4127 & 0.15145 & $\mathrm{~N}$ & 1.4910 & 0.14698 & $\mathrm{~N}$ & 0.047 & $B$ \\
\hline Jujur & 1.4423 & 0.11007 & $\mathrm{~N}$ & 1.5503 & 0.16433 & $\mathrm{~N}$ & 0.004 & B \\
\hline Disiplin & 1.4103 & 0.22224 & $\mathrm{~N}$ & 1.4943 & 0.26445 & $\mathrm{~N}$ & 0.188 & TB \\
\hline Tanggungjawab & 1.5423 & 0.11307 & $\mathrm{~N}$ & 1.5727 & 0.13741 & $\mathrm{~N}$ & 0.354 & TB \\
\hline Toleransi & 1.4337 & 0.11312 & $\mathrm{~N}$ & 1.4640 & 0.14543 & $\mathrm{~N}$ & 0.371 & TB \\
\hline Gotongroyong & 1.4827 & 0.14137 & $\mathrm{~N}$ & 1.6467 & 0.12794 & $\mathrm{~N}$ & 0.000 & B \\
\hline Santun & 1.5893 & .21595 & $\mathrm{~N}$ & 1.6310 & 0.17343 & $\mathrm{~N}$ & 0.413 & TB \\
\hline Percaya diri & 1.5267 & .15430 & $\mathrm{~N}$ & 1.5913 & 0.15404 & $\mathrm{~N}$ & 0.110 & TB \\
\hline
\end{tabular}

Keterangan:

SB : Simpangan BakuB: BermaknaTB: Tidak Bermakna

$\mathrm{N}$ : Data berdistribusi Normal

Dari Tabel 1.2 menunjukkan bahwa nilai $\mathrm{p}$ dari variabel sikap Pretest kelas kontrol dengan Pretest kelas untuk masing-masing sikap yaitu sikap spiritual, nilai $\mathrm{p}$ yang didapat sebesar 0.047 ( $p<0.05)$. Dari data tersebut dapat diartikan bahwa setiap mahasiswa sebelum perlakuan memiliki sikap spiritual yang berbeda-beda.Nilai $\mathrm{p}$ yang didapat dari sikap jujur yaitu sebesar $0.004(p<0.05)$ yang diartikan bahwa sikap jujur setiap mahasiswa di kelas kontrol maupun eksperimen berbeda-beda sebelum dilakukan perlakukan. Pada sikap gotong royong nilai $p$ yang didapat sebesar $0.001(p<$ 0.005) yang berarti bahwa sikap gotong royong pada kelompok kontrol dan eksperimen memiliki perbedaan.Pada sikap disiplin, tanggungjawab, toleransi, santun, dan percaya diri nilai $p$ yang didapat lebih besar dari 0.05, dapat diartikan bahwa pada sikap tersebut sikap mahasiswa dapat dikatakan tidak berbeda bermakna sebelum perlakuan diberikan.

Setelah dilakukan uji pre-test terhadap keseluruhan sikap yang dikaji, 
selanjutnya dilakukan uji terhadap posttest antara kelompok kontrol dan kelompok eksperimen. Hasil dari uji statistic tersebut disajikan pada Tabel 3.

Tabel 3. Hasil Uji Statistik Independent t-test dari Data Post-test Kelas Kontrol dan Kelas Eksperimen pada Masing-masing Sikap

\begin{tabular}{|c|c|c|c|c|c|c|c|c|}
\hline \multirow{2}{*}{ Variabel } & \multicolumn{2}{|c|}{ Kelompok Kontrol } & \multirow[t]{2}{*}{ Ket. } & \multicolumn{2}{|c|}{$\begin{array}{l}\text { Kelompok } \\
\text { Eksperimen }\end{array}$} & \multirow[t]{2}{*}{ Ket. } & \multirow{2}{*}{$\begin{array}{l}\text { Nilai } \\
p\end{array}$} & \multirow{2}{*}{ Keterangar } \\
\hline & Rerata & SB & & Rerata & SB & & & \\
\hline Spiritual & 1.5083 & 0.15523 & $\mathrm{~N}$ & 2.8650 & 0.17280 & $\mathrm{~N}$ & 0.001 & $B$ \\
\hline Jujur & 1.5183 & 0.17285 & $\mathrm{~N}$ & 2.7780 & 0.13912 & $\mathrm{~N}$ & 0.001 & B \\
\hline Disiplin & 1.6380 & 0.36835 & $\mathrm{~N}$ & 2.7610 & 0.26959 & $\mathrm{~N}$ & 0.001 & B \\
\hline $\begin{array}{c}\text { Tanggung } \\
\text { jawab }\end{array}$ & 1.6660 & 0.15817 & $\mathrm{~N}$ & 2.8713 & 0.24018 & $\mathrm{~N}$ & 0.001 & B \\
\hline Toleransi & 1.5293 & 0.19936 & $\mathrm{~N}$ & 2.9573 & 0.28025 & N & 0.001 & B \\
\hline $\begin{array}{l}\text { Gotong } \\
\text { royong }\end{array}$ & 1.6717 & 0.18983 & $\mathrm{~N}$ & 3.1837 & 0.28314 & $\mathrm{~N}$ & 0.001 & B \\
\hline $\begin{array}{l}\text { Sopan } \\
\text { Santun }\end{array}$ & 1.7910 & 0.18408 & $\mathrm{~N}$ & 3.2410 & 0.32488 & $\mathrm{~N}$ & 0.001 & B \\
\hline Percaya Diri & 1.7097 & 0.13077 & $\mathrm{~N}$ & 2.9630 & 0.19418 & $\mathrm{~N}$ & 0.001 & B \\
\hline
\end{tabular}

Dari Tabel 3 tampak bahwa nilai $p$ dari variabel sikap spiritual, jujur, disiplin, tanggungjawab, toleransi, gotongroyong, sopan santun, dan percaya diri lebih kecil dari 0,05 ( $p<0,05)$, yaitu untuk masing-masing sikap 0,001 < 0,05 . Hal ini berarti bahwa antara kelompok kontrol dan kelompok eksperimen baik pada data sikap spiritual, jujur, disiplin, tanggungjawab, toleransi, gotong-royong, santun, dan percaya diri adalah berbeda bermakna. Dengan diperolehnya nilai $p$ yang berbeda bermakna maka dapat dikatakan bahwa materi ajar yang disertai dengan muatan local genius diasumsikan berpengaruh terhadap sikap spiritual, jujur, disiplin, tanggung jawab, toleransi, gotong-royong, santun, dan percaya diri siswa. Dengan kata lain dapat dinyatakan bahwa materi ajar yang berorientasi pada local genius berpengaruh secara nyata terhadap hasil penelitian ini, yaitu perubahan sikap mahasiswa. Untuk menjelaskan gambaran tentang keseluruhan sikap mahasiswa pada kelas kontrol dan kelas eksperimen, sebelum proses pembembelajaran, dapat dibuatkan grafik seperti tampak pada Gambar 2.

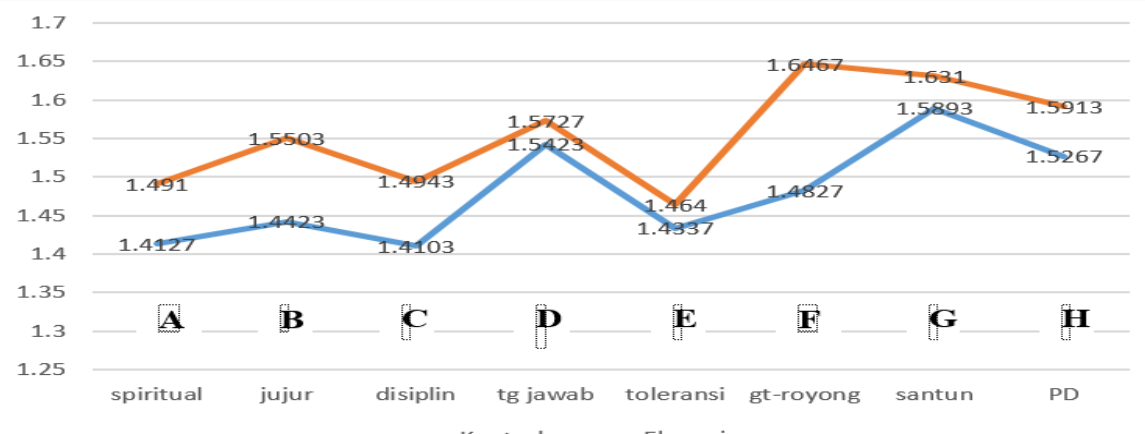

Gambar 2. Grafik tentang Sikap Mahasiswa pada Kelas Kontrol dan Kelas Eksperimen Sebelum Proses Pembembelajaran 
Dari grafik pada Gambar 2 di atas terlihat bahwa rerata setiap sikap sebelum pembelajaran, pada kelas kontrol dan kelas eksperimen memiliki hasil sebagai berikut: sikap spiritual $(A)$, jujur (B), gotong-royong (F) menunjukkan interval rerata yang signifikan. Hal ini dapat dilihat dari grafik dari kelas kontrol dan eksperimen yang tidak berhimpitan. Berdasarkan data tersebut dapat diinterpretasikan bahwa pada ketiga sikap ini, pada kedua kelas menujukkan perbedaan yang bermakna. Namun di sisi lain sikap disiplin (C), tanggungjawab (D), toleransi $(E)$, santun $(G)$, percaya diri
(H) menunjukkan interval rerata yang tidak signifikan dan dapat dilihat dari grafik sikap-sikap ini yang berhimpitan. Hal ini berarti bahwa tidak ada perbedaan yang nyata sikap mahasiswa (C, D, E, F, G, H) antara kelompok kontrol dengan kelompok eksperimen.

Untuk mengetahui kondisi sikap mahasiswa setelah diberikan perlakuan, pada kelas kontrol dan kelas eksperimen, setelah proses pembembelajaran, selanjutnya disajikan grafik seperti tampak pada Gambar 3.

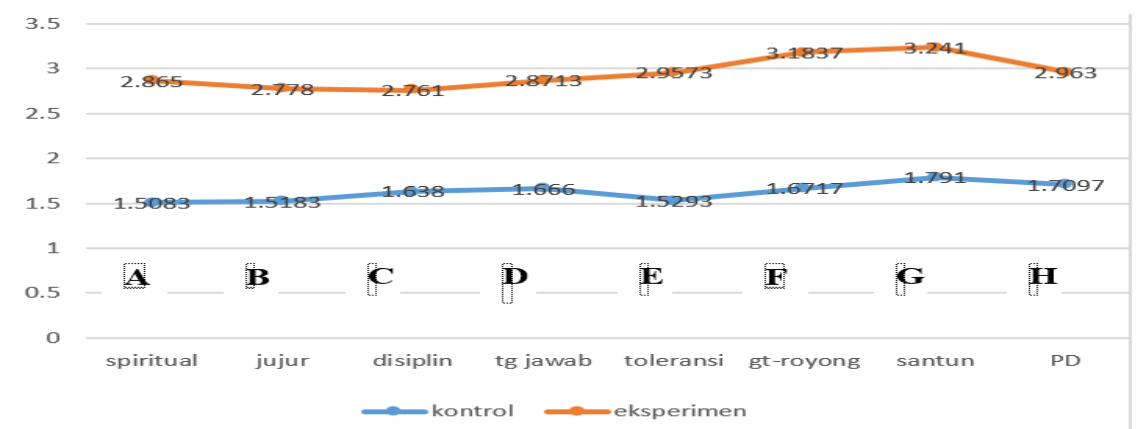

Gambar 3 Grafik tentang Sikap Mahasiswa pada Kelas Kontrol dan Kelas Eksperimen Setelah Proses Pembembelajaran

Dari grafik pada Gambar 3 di atas, terlihat bahwa rerata setiap sikap setelah pembelajaran pada kelas kontrol dan kelas eksperimen memiliki hasil sebagai berikut: bahwa kedua kelas menunjukkan interval rerata yang signifikan. Hal ini dapat dilihat dari grafik dari kelas kontrol dan eksperimen yang tidak berhimpitan.Berdasarkan data tersebut dapat diinterpretasikan bahwa pada semua sikap pada kedua kelas, menujukkan perbedaan yang bermakna.

Lebih lanjut gambaran tentang selisih sikap mahasiswa pada kelas kontrol dan kelas eksperimen sebelum dan setelah proses pembembelajaran, selanjutnya dibuatkan grafik seperti tampak pada Gambar 4.

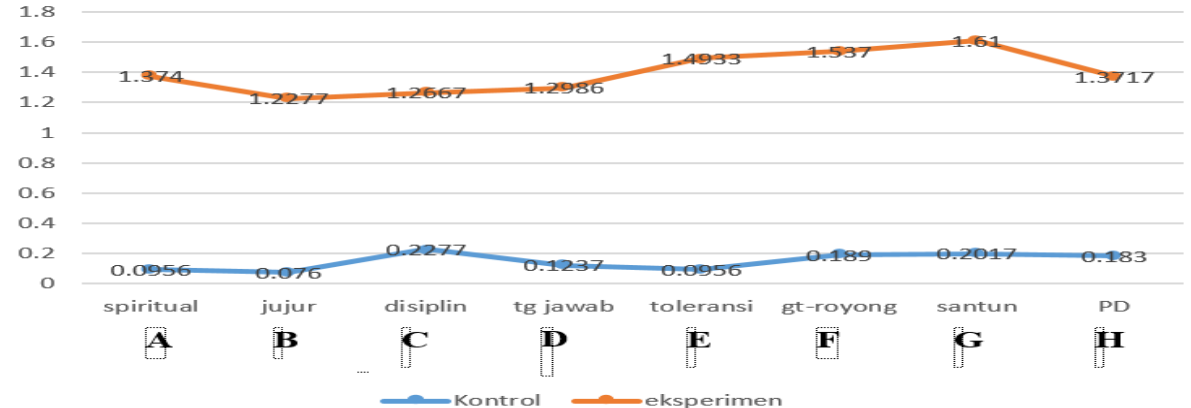

Gambar 4. Grafik tentang Selisih Sikap Mahasiswa pada Kelas Kontrol dan Kelas Eksperimen Sebelum dan Setelah Proses Pembembelajaran 
Grafik pada Gambar 4 terlihat bahwa rerata selisih sikap setelah dan sebelum pembelajaran pada kelas kontrol dan kelas eksperimen memiliki hasil sebagai berikut: bahwa kedua sikap tersebut menunjukkan interval rerata yang signifikan dapat dilihat dari grafik dari kelas kontrol dan eksperimen yang tidak berhimpitan. Berdasarkan data tersebut dapat diinterpretasikan bahwa pada semua sikap pada kedua kelas menujukkan perbedaan bermakna.

Setelah mahasiswa diajarkan menggunakan model pembelajaran berbasis karakter dengan kearifan local (Alfian, 2012; Chrisiana, 2005;), konsep tentang etika lingkungan yang

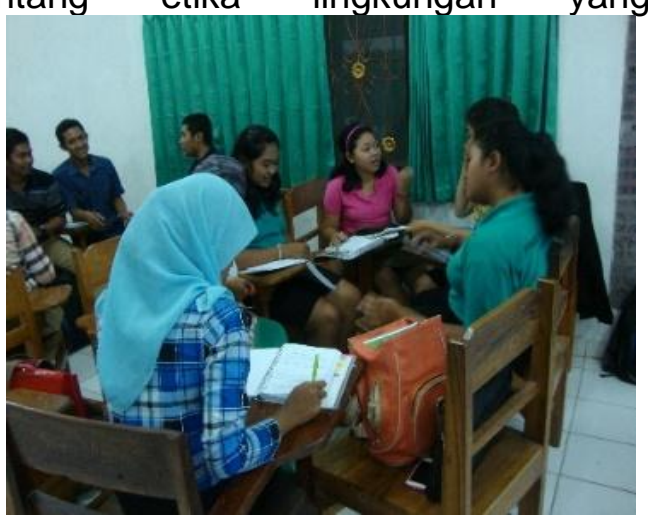

Gambar 5 Kegiatan Diskusi yang Memperlihatkan Sikap Gotong-Royong.

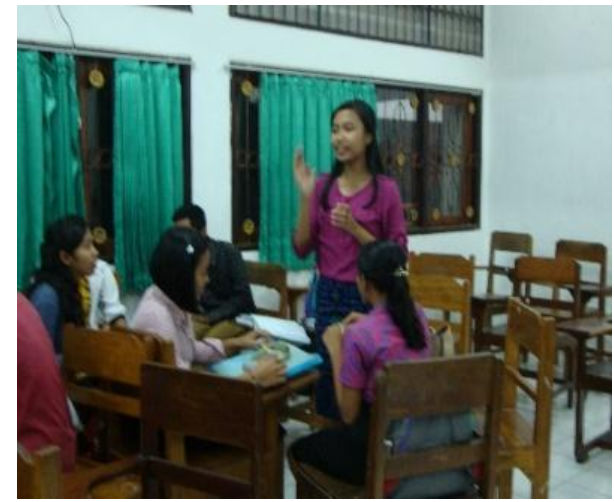

Gambar 7 Kegiatan Penyampaian Argumentasi yang Memperlihatkan Sikap Percaya Diri.

Pengaruh penggunaan pendidikan karakter berorientasi kearifan lokal pada proses pembelajaran dapat ditinjau dari hasil penilaian sikap setelah proses pembelajaran yakni pada kelompok kontrol sebesar (13.03) dan kelompok eksperimen sebesar $(23,62)$. Setelah berhubungan dengan Tri Hita Karana (Geriya, 2007), terlihat bahwa sikap mahasiswa mengalami perubahan. Hal ini dikarenakan kesadaran mahasiswa mengenai hubungannya dengan Tuhan, Alam, dan dengan sesama manusia harus berjalan selaras. Mahasiswa juga memperlihatkan sikap yang selalu disiplin dan santun. Ketika mahasiswa dilatih untuk mengucapkan salam sebelum berargumentasi atau memberikan pendapat, sikap mahasiswa sudah menunjukkan hal yang signifikan, karena pada akhirnya mahasiswa sudah terbiasa untuk mengucapkan salam sebelum berargumentasi.

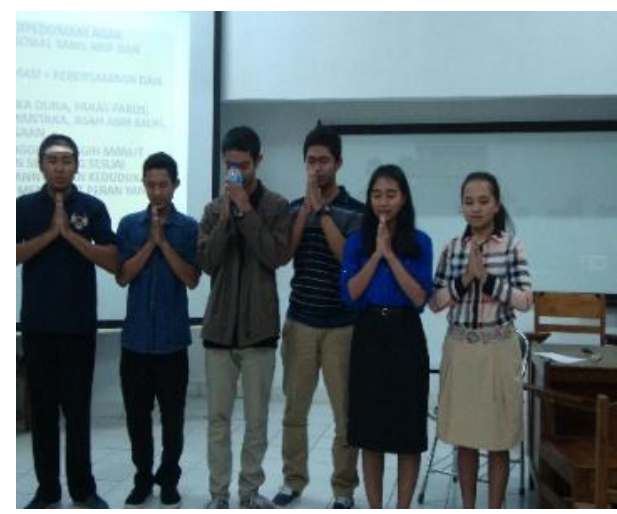

Gambar 6 Kegiatan Presentasi yang Memperlihatkan Sikap Spiritual

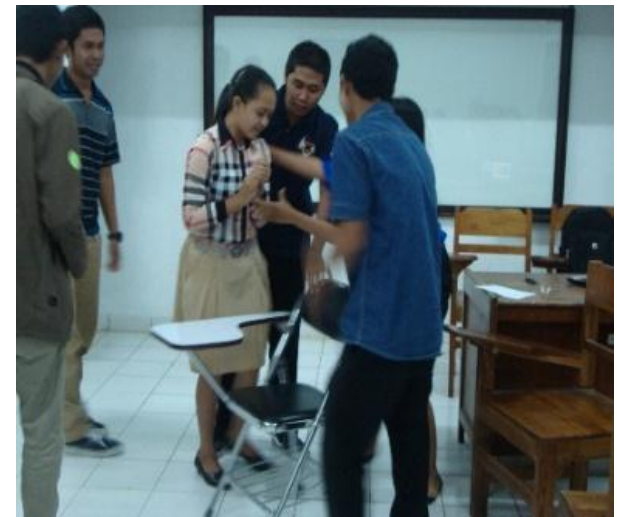

Gambar 8 Kegiatan Role Playing yang Memperlihatkan Sikap Toleransi

diuji menggunakan independent t-test nilai sikap setelah pembelajaran menunjukkan perbedaan yang bermakna dengan nilai $(p<0,05)$.

Perbedaan bermakna pada nilai setelah pembelajaran menunjukkan jauhnya pengaruh pengintegrasian pendidikan karekater berorientasi 
kearifan lokal pada proses pembelajaran IPL terhadap sikap mahasiswa. Hal ini memiliki pengertian bahwa pendidikan karakter yang dilakukan dengan mengorientasikannya secara kontekstual melalui kearifan lokal yang dekat dan menjadi dasar budaya yang secara tidak disadari mahasiswa telah mengakar pada kehidupan sehari-hari.Kenyataankenyatan sehari-hari yang telah ada dalam kehidupan mahasiswa yang mulai disadari sebagai nilai luhur yang patut ditiru dan digugu, mengakibatkan kesadaran mahasiswa untuk menigkatkan karakternya yang dapat dilihat dari perubahan nilai pada sikapsikap yang digunakan sebagai indikator (Erwan, 2012; Mundilarto, 2013; Sartini, 2004).

Seberapa

jauh pengaruhpengintegrasian pendidikan karakter berorientasi kearifan lokal pada pembelajaran IPL juga dapat dilihat dari peningkatan sikap setelah pembelajaran ditunjukkan dengan rerata sebelum dan setelah pembelajaran. Pada kelas kontrol rerata sebelum pembelajaran sebesar (11.84) dan setelah pembelajaran sebesar (13.03) sehingga presentase peningkatannya sebesar $10,06 \%$. Pada kelas eksperimen rerata sebelum pembelajaran sebesar (12.44) dan setelah pembelajaran sebesar (23.62) sehingga persentase peningkatannya sebesar $89,87 \%$. Pada kelas kontrol dan kelas eksperimen keduanya menunjukkan perbedaan yang bermakna pada sikap sebelum dan setelah pembelajaran karena berdasarkan hasil uji dengan uji paired t-test pada masing-masing kelas menunjukkan nilai $(p<0,05)$. Namun dapat diamati bahwa presentase peningkatan yang lebih tinggi terjadi pada kelompok eksperimen.

Sikap secara umum merupakan suatu tingkah laku yang didasarkan proses belajar. Hal inilah yang menyebabkan perubahan pada kedua kelas untuk sikap secara umum memiliki perbedaan yang bermakna. Pada kelas kontrol perbedaan bermakna ini disebabkan oleh sikap alamiah manusia dan proses belajar yang dialaminya. Pada kelompok eksperimen kontrol secara intensif juga mengalami proses pembelajaran dan secara individual mengerti bahwa dirinya sedang diamati sikapnya. Pada sisi lain peningkatan yang begitu besar terjadi pada kelas ekperimen. Peningkatan pesat pada kelas eksperimen menunjukkan bahwa adanya pengaruh pengintegrasian pendidikan karakter berorientasi kearifan lokal yang diselipkan dalam proses pembelajaran IImu Lingkungan.

\section{SIMPULAN DAN SARAN}

Berdasarkan uraian hasil penelitian di atas maka simpulan yang dapat disampaikan adalah bahwa pengintegrasian pendidikan karakter berorientasi kearifan lokal ke dalam materi ajar mata kuliah IImu Lingkungan dengan pendekatan CTL dapat berpengaruh untuk meningkatkan soft skill mahasiswa Jurusan Pendidikan Biologi FMIPA Undiksha.

\section{DAFTAR PUSTAKA}

Alfian, Magdalia. 2012. Potensi Kearifan Lokal dalam Pembentukan Jati Diri dan Karakter Bangsa dalam Prociding the $5^{\text {th }}$ International Confference on Indonesian Studies : Etnicity and Globalization. pp 428-435.

Asmani, Jamal Makmur. 2011. Buku Panduan Internalisasi Pendidikan Karakter Di Sekolah. Jogjakarta: Diva Press.

Buchori., Manajemen Corporate dan StrategiPemasaran Pendidikan Fokus pada Mutu dan Layanan Prima, Bandung: Alfabeta, 2008.

Chrisiana, Wanda. 2005. Upaya Penerapan Pendidikan Karakter Bagi Mahasiswa (Studi Kasus di Jurusan Teknik Industri UK Petra). Dimuat dalam Jurnal Teknik Industri Vol. 7, No. 1, Juni 2005: pp $83-90$.

Depdiknas. 2010. Bahan Pelatihan Penguatan Metodologi Pembelajaran Berdasarkan 
Nilai-nilai Budaya untuk Membentuk Daya Saing dan Karakter Bangsa, oleh Pusat Kurikulum Departemen Pendidikan Nasional, 2010. Diakses melalui situshttp://rumahinspirasi.com/1 8-nilai-dalam-pendidikankarakter-bangsa/ pada tanggal 07 Maret 2014 jam 02:43 PM

Erwan Baharudin. 2012. Kearifan Lokal, Pengetahuan Lokal dan Degradasi Lingkungan. Tersedia dalamhttp://www.esaunggul.ac.i d/epaper/kearifan-lokalpengetahuan-lokal-dandegradasi-lingkungan/. Diakses tanggal7 Maret 2013

Geriya, I Wayan. 2007. Konsep dan Strategi Revitalisasi Kearifan Lokal dalam Penataan Lingkungan Hidup Daerah Bali. Dalam Buku Kearifan Lokal Dalam Pengelolaan Lingkungan Hidup. Denpasar : UPT Penerbit Universitas Udayana.

Kemendiknas.2013. Pembinaan

Pendidikan Karakter di Sekolah Menengah Pertama.Jakarta: Kementerian Pendidikan dan Kebudayaan Direktorat Jenderal Pendidikan Dasar Direktorat Pembinaan Sekolah Memengah Pertama.

Khan, Yahya. 2010. Pendidikan Karakter Berbasis Potensi Diri. Yogyakarta: PelangiPublishing

Lickona, Thomas. 2012. Mendidik Untuk Membangun Karakter" Bagaimana Sekolah dalam Memberikan Pendidikan Tentang Sikap Hormat dan Bertanggung jawab" judul asli: Educatingfor Character: How Our Schools Can Teach Respect And Reponsibility. Jakarta: Bumi Aksara

Mundilarto. 2013. Membangun Karakter Melalui Pembelajaran Sains. Dimuat dalam Jurnal Pendidikan Karakter, Tahun III, Nomor 2, Juni 2013 pp: 153-163.
Nugroho, Tofiq. Implementasi Nilai-Nilai Dasar Pendidikan Karakter Bangsa dalam Pembelajaran di SMK Muhammadiyah 4 Surakarta. Jurnal Mediasi. 2011

Pocock, S.J. 1986. Clinical Trials, A Practical Approach. New York: A Willey Medical Publication.

Raka, Gede dkk. 2011. Pendidikan Karakter di Sekolah; dari Gagasan ke Tindakan. Jakarta: Elek Media Komputindo

Sartini. 2004. Menggali Kearifan Lokal Nusantara Sebuah Kajian Filsafati. Jurnal Filsafat, Agustus 2004, Jilid 37, Nomor 2 pp:111120.

Thamrin. Karakter Budaya Akademik dan Hubungannya dengan Prestasi Belajar Mahasiswa Jurusan Pendidikan Ekonomi FE Universitas Negeri Medan.Jurnal Mediasi vol. 4.No.1. 2012

Wijana, Nyoman. 2009. IImu Lingkungan. Denpasar : Fakultas Kedokteran-Undiksha Press

Wijana, Nyoman; Agus Dharmadi. 2012. Meta Analisis Hasil Penelitian Model Pelatihan dan Pendidikan Kecakapan Hidup Berbasis IPTEKSO Undiksha dan Rancangan Pengembangannya. Laporan Hasil Penelitian DIPA Undiksha. Tidak Diterbitkan. 